\title{
The influence of promotional activities on the economic decision making
}

\author{
Asl1 Öztopcu ${ }^{1}$ \\ Nuran Karaağaoğlu ${ }^{2}$
}

\begin{abstract}
Behavioral economics is one of the sub-disciplines discussed through the process of economic thought. It studies the economic decisions of the individuals under the influence of social, emotional and cognitive factors. According to the rational behavior theory in economics, it is discussed that, the individuals may show irrational behaviors in spite of the expectation of rational behaviors. Economics is a human focused social science. The studies held, illustrate that the human behaviors have to be evaluated with the psychological factors.

The purpose of this study is to investigate the influence of sales efforts of the drug firms on the economic decision making. The data gathered by the questionnaire show that the marketing strategies influence the decision making behavior of individuals.
\end{abstract}

Keywords: Behavioral Economics; Rational Behavior; Economic Choices; Decision Making.

Jel code: A13, B3, D03, M3

\section{Introduction}

The economics discipline investigates the distribution of short income over the endless individual demands. The rationality concept which is one of the basic assumptions in the classical economic understanding is evaluated in different ways at new economic understanding. Rational individual behavior which may be qualified as the definition of rationality concept is criticized since the early times. While some economists think that the individual behaviors are irrational rather than being rational, other economists defend that the irrational behaviors are also rational.

In spite of the fact that the behavioral economics is seen as a new understanding, the studies conducted date back to old times. Adam Smith (1759) was the one of the first economists who explains the effect of psychology on the individual behaviors in his study of "The Theory of Moral Sensiment". James Mill (1773-1836) and John Stuart Mill (1806-1873) mention the existence of the psychological effects on the preference of right employment and division of labor.

Scholars during the neoclassical revolution at the turn of the 20th century. The economists; Daniel Kahneman and Amos Tversky (1979), George Akerlof (2001), Matthew Rabin and John Bates Clark (2001), who have studies in this field; were awarded by the Economy Nobel Prize for their studies illustrating the influence of psychology on the individual behaviors (Azar, 2012: 662-663).

1 Ph.D., Maltepe University, Department of Banking and Insurance, aoztopcu@gmail.com

${ }^{2}$ Lecturer, Master. Maltepe University, Department of Public Relations and Publicity, nurankaraagaoglu@maltepe.edu.tr 
Öztopcu, A., \& Karaağaoğlu, N. (2016). The influence of promotional activities on the economic decision making. Journal of Human Sciences, 13(3), 4613-4626. doi:10.14687/ihs.v13i3.3947

Scholars, increasingly tried to emulate the natural sciences, as they wanted to differentiate themselves from the then "unscientific" field of psychology (Samson, 2014: 2).

\section{Behavioral Economics and Rational Behavior}

According to the traditional economics understanding, the individuals are not influenced from internal and external factors and show rational behaviors. However, the studies conducted illustrate that, contrary to the "Theory of Rational Behavior" the individuals decide by the influence of psychological factors.

In this context, behavioral economics states that the rationality assumption is not valid under all circumstances and to nominate all the individuals rational may lead to incorrect presumptions (Yalçı, 2012:2).

In this context, according to the theory of classical economy, economic human (Homo Economicus) demonstrates rational behavior. Also they are sordid and selfish because of wanting to know what he demands every time. Those behaviors cause maximizing individual value. At the same time economic human has full information in every occasion (Schneider, 2010: 4).

As it is seen above, according to the rational choice theory, individual's achievement of optimal utility depends on his knowledge about the necessary resources and his determination of the cost for these resources. However, the researches indicate that the individuals do not have this equipment every time.

Accordingly, behavioral economics, is searching answers to questions such as the following (Akin, 2013: 1):

- Why we owe because of credit cards?

- Why we collect the items that are not used in the closet?

- Why do we buy unnecessary things?

Researchers are trying to answer these questions. In this regard the founder of the micro economics Alfred Marshall (1842-1924), approaches the individual as a social existence. He dealt with the political, social and personal life of the individual through the economic context. Therefore, he suspected to explain the economic truth by only mathematics (Nakano, 2007:62).

Many economists like Marshall make researches on human behaviors. In this context, the study of Kahneman \& Tversky (1979) called "Prospect Theory" is very significant. In the study, it was determined that under the condition of risk, the individuals behave in a tendency of avoiding from the risk. The significant emphasis in the theory is instead of preferring the most profitable alternative, the preference of the most reliable choice by avoiding risk. In this context, according to the Tversky \& Kahneman (1986); the theory of rational choice has four main principles of invalidity, transitivity, dominance and variability. These principles change the rational choice behavior of the individuals.

This condition is not valid every time and in every occasion. This leads to Herbert Simon's (1955) "bounded rationality" theory's being admitted. However the validity of this hypothesis can be possible by the influence of "heuristics" and "tendencies" in the decision making process (Yalçin, 2012: 15). Accordingly, while the uncertainty and insufficient knowledge are composing the base of rationality theory, it also supports the theory of individual's cannot have full information every time. 
Öztopcu, A., \& Karaağaoğlu, N. (2016). The influence of promotional activities on the economic decision making. Journal of Human Sciences, 13(3), 4613-4626. doi:10.14687/ihs.v13i3.3947

The researchers conducted about decision-making under the uncertainty and risk, are important for behavioral economics. The study by Von Neumann \& Morgenstern (1953) the decisions given by the individuals under the uncertainty were investigated. As a result of the research, they determined that there is a relationship between expected value and rational decision-making criteria at their study "Theory of Games and Economic Behavior" (Von Neumann \& Morgenstern, 1953: 55-57). In this context, the expectation theory criticizes the theory of expected value and indicates that individuals can take different decisions through the economic decision-making process.

The concept of individual for the economic human included in psychology discipline is different from the individual in classical economy. According to this theory, the individual takes the right decision for himself. However, all his decisions are not taken by thinking to maximize his interests. The basic approach at this behavior is the satisfaction of the individual. Because, when the behaviors of the individual are investigated, it is seen that he can take different decisions for similar cases. Many factors can shape the demands while individual's needs are motivated and converted to a demand.

The demographic and personal characteristics and psychological state of the individual cause him to have different needs from others. Besides, in spite of the fact that there is an increase in the number of researchers approaching the behavioral economics with tolerance and the number of studies has remained, there is still a prejudice and opposition for psychology taking place in the economy discipline (Frank, 2006: 395).

The individual which is terminated as "homo economicus" in classical economics, is renamed as "homopyschologicus" by the inclusion of psychology discipline (Seniğne, 2011: 37). The purpose of admitting this approach is the consideration of the effectiveness of human psychology on the economy. Because, Homopyschologicus approach states that the individuals can not realize their economic interests rationally because of the different factors like lack of knowledge, prestige, statute, vanity and personal relationships.

"Prospect Theory" (decision-making under risk) which is in the literature of economy occurs within the utility theory of economy. Uncertainty is not to know which choice is suitable. The preference of one choice changes the economic behaviors. Uncertainty is to know more than one case may occur, but not to know which one will occur. When the case occurs, the economic relationship is affected and change.

In a research conducted "Coherent Arbitrariness: Stable Demand Curves Without Stable Preferences" study by Ariely, Loewenstein, \& Prelec (2003), the consumers attitude for paying more for wireless keyboard was detected, and the majority of the consumers were shown that they were keen on paying more for the new technology (Ariely, Loewenstein \& Prelec, 2013: 77 ). Accordingly, the psychology of having new, increased the demand of commodity.

Akerlof \& Kranton (2000) states in their study of "Economics and Identity" that, the identity psychology and gender difference affects the decisions of the individuals in the fields like employment, cooperation and income.

As it is seen above, the individuals do not behave rationally in the decision-making. They take irrational decisions because of the psychological factors. Some of these factors are the marketing activities held by the firms in order to increase the sales. Advertising, discount, promotion and other advantages influence the decision-making of the individuals. These effects are evaluated within the research field of behavioral economics understanding. Behavioral economics can be 
Öztopcu, A., \& Karaağaoğlu, N. (2016). The influence of promotional activities on the economic decision making. Journal of Human Sciences, 13(3), 4613-4626. doi:10.14687/jhs.v13i3.3947

defined as to investigate why an individual prefers " $y$ " instead of " $x$ " for consumption or investment.

Keynes (1921) states in his study of "A Treatise on Probability" that, in the case of uncertainty the only resource of information is belief and perception. This is a determination that should be insisted on for behavioral economics (Aksoy \& Sahin, 2009: 4).

However, despite these examples, through the economic conception process, by the Neo-classical Economic Theory's becoming widespread, economy has changed over social sciences (Calik \& Düzü, 2009: 2). In order to explain this change, Camerer issues the situation of rationality principle at the classical economics for the behavioral economics (Camerer 1999).

Table-1: The Substitution of Rationality Principle at Behavioral Economics

\begin{tabular}{|c|c|c|}
\hline Rationality Principle & Behavior Principle & Psychological Base \\
\hline $\begin{array}{l}\text { Expected Value } \\
\sum_{i} P_{\mu}\left(X_{i}\right)\end{array}$ & $\begin{array}{l}\text { Expectancy Theory } \\
\sum_{\mathrm{i}} \pi\left(\mathrm{p}_{\mathrm{p}}\right) \mathrm{u}\left(\mathrm{x}_{\mathrm{i}}-\mathrm{r}\right)\end{array}$ & $\begin{array}{l}\text { Psychophysical Integration: } \\
\text { Non-linear } \pi\left(P_{i}\right) \text {. }\end{array}$ \\
\hline Stability & Learning, Development & Generalized Recommendation \\
\hline $\begin{array}{l}\text { Discounted Value } \\
\sum_{t} \delta^{t} u\left(x_{t}\right)\end{array}$ & $\begin{array}{l}\text { Hyperbolic Discount } \\
u\left(X_{0}\right)+\sum_{t=1} \beta \delta^{t} u\left(X_{t}\right)\end{array}$ & Preference of Urgency \\
\hline $\begin{array}{l}\text { Maximization of Self- } \\
\text { Payment } u_{X 2}^{1}\left(X_{1}, X_{2}\right)=0\end{array}$ & $\begin{array}{l}\text { Social Value } \\
u_{X 2}^{1}\left(X_{1}, X_{2}\right) \neq 0\end{array}$ & $\begin{array}{l}\text { Consumption for Others } \\
\text { (Reciprocity, Inequality) }\end{array}$ \\
\hline
\end{tabular}

Reference: Camerer, C. (1999). Behavioral economics: Reunifying Psychology and Economics. Proceedings of the National Academy of Sciences of the United States of America, 96(19), 10576.

As it is seen from the table-1, behavioral economics submits psychological based mathematical alternatives to the rationality assumption. However, the basic factor of the criticisms is the conversion of psychological factors into mathematical statements. Nonetheless, it is seen in the studies that the mathematical alternatives composed are effective in the different fields like economy, finance and law.

The behavioral economics understanding enforces the view of rational behavior approach to change. Besides, other than the standard behaviors expected from the individual, the concepts of unlimited rationality, unlimited desire and unlimited self-interest are being questioned (Thaler \& Mullainathan, 2000: 3-4).

In 1940's, the economists started to use experimental methods in order to test their economic theories at real world. The experimental economic studies increased whereas there were only 50 yearly at 1980's. Mill was one of the first economists who interested in the field with the economic point of view. Mill defends the statement of the impossibility of the implementation the experimental economy. Additionally, Milton Friedman is also one of the economists opposing the experimental economy. Nonetheless, since 1950's the economists as Siegel, Goldstein, Davis and Williams conducted studies that supported experimental economics.

In behavioral economics and the subfields experimental economics and neuroeconomics, the rationality comes out at decisions taken and in the preferences. These decisions and choices are shaped by overtrust, optimism, probabilities and intuition (Thaler \& Mullainathan, 2000: 8-10).

According to economist Tim Harford (2008), the individuals inherently have rational behavior. However, if there are many choices, cognitive restraint comes in. Some economists state this 
Öztopcu, A., \& Karaağaoğlu, N. (2016). The influence of promotional activities on the economic decision making. Journal of Human Sciences, 13(3), 4613-4626. doi:10.14687/jhs.v13i3.3947

situation as utility maximization. The optimal behavior model shows instability across these choices (Eren, 2009: 26; Harford, 2008: 179). Achieving similar results with similar studies causes the assumption of the irrational behaviors of the individual affected by advertisements, promotion and price. The studies conducted for the decisions of the individuals illustrates that cautionary factors like music, visual instruments and advertising lead to dependent variable of consumers (Dİclemente \& Hantula, 2003: 590).

\section{Neuroeconomics}

Behavioral economics which can be seen as complementary for neo-classical economy, aims to investigate the human behaviors within the limits of rational behavior theory. By investigating the psychological factors, the irrational behaviors were started to be studied (Colander, 2004: 10). Neuroeconomy reveals how psychological factors influence the individuals.

Neuroeconomy investigates the relationship between decision-making and the human brain in order to learn the behaviors of the individual for economic decisions. By using functional magnetic resonance (fMRI) imaging, transcranial magnetic (TMI) imaging, pharmacological factors and similar techniques, the micro formation of all the activities in the neural system is tried to be researched (Camerer, Loewenstein \& Prelec, 2005: 12).

By the "Signal Detection Theory and psychophysics", Green \& Swets (1966) tried to explain how human behavior is affected. Ferrier (1878), Newsome \& Movshon (1989), Glimcher \& Sparks (1992) studied how the individuals take decisions (Glimcher, Camerer, Fehr \& Poldrack, 2009: 5).

However, to conduct experimental studies in the economics discipline is impossible. For this reason, behavioral economics focuses on if the individuals are affected from external factors or not, instead of the reason of the influence of these factors.

\subsection{Experimental Economics}

While it is discussed whether an experiment can be conducted at economy or not till the near future, in the last years, new developments can be achieved by experimental economy in both macro and micro economy. The difference of the experimental economy and neuroeconomics is the utilization of various science branches like biology, mathematics and sociology with psychology. The field researches are regarded as same with laboratory studies. The research fields of experimental economy are the markets, decision making and social choices (Eren, 2009: 26).

Nevertheless, Mill (1967), claims that conducting experimental studies at social sciences is hard. Therefore, multi-disciplinary studies are needed. Samuelson \& Nordhaus (1985) states the economists' not having experimental practices as below (List, 2011: 3; Basilgan, 2013: 64):

"...economists have no such luxury when testing economic laws. They cannot perform the controlled experiments of chemists or biologists because they cannot easily control other important factors. Like astronomers or meteorologists, they generally must be content largely to observe..."

The studies conducted on this field shows that the experimental economy is closely related with economic issues. The studies of Fehr \& Schmidt (1999, 2003, 2004) illustrates how the emotional states of human affects the decision making behavior of the individual. Similarly, "The Behavioral Play Theory of Camerer" Camerer (2003), the studies of Ledyard (1995) and Sally (1995) are some of the studies evaluating the economic issues by experimental economics (Binmore \& Shaked, 2009: 4). 
Öztopcu, A., \& Karaağaoğlu, N. (2016). The influence of promotional activities on the economic decision making. Journal of Human Sciences, 13(3), 4613-4626. doi:10.14687/jhs.v13i3.3947

The economists usually state that the individual acts rationally and with self-interest while explaining the market behavior. They regard the difference composed by the external incentives as natural from the economic point of view. However, they do not discuss about internal effects of the individual. Economists try to explain these internal incentives by the abstract concepts like belief. The disregarded internal incentives are identified in the field of experimental economics (Kahneman \& Tversky, 1979: 274).

Experimental economics focuses on the psychological impact levels of individuals like neuroeconomics. The data gathered gives opportunity for proving the reasons of individual's taking different decisions. Nonetheless, the whole admission of both fields is hard for economics discipline. It will contribute to behavioral economics by studying with other disciplines.

\section{The Influence of Behavioral Economics}

Today's behavioral economics understanding is not the substitute but the supplementary of neoclassical economics. The understanding of behavioral economics has an impact area on the economic understanding (Gorvett, 2012: 5-6).

The behavioral economics indicates that the individuals behave irrationally at the optimal decisions that they take for themselves. The issues like imperfection of economic administration of countries, economic crisis resulted in the investigation of psychological effects for the behavioral economics (Bolton \& Ockenfels, 2012: 668). All fields influenced by psychology institutes the research fields of behavioral economics. If it is explained by the studies conducted, the economic fields like employment, production, finance are the topics mostly insisted on.

In today's understanding it is seen that some countries utilize behavioral economics. It can be used to make assumptions about many issues effective in the market like asset risks, marginal value of consumption, stock assumptions and to manipulate the consumer. For this reason, the development of "behavioral finance" theories can be an opportunity for investors and the government (Camerer, 2002). It can be used for positive studies like increasing the rates of savings, providing the usage of productive energy, innovation, taxes, contributions and the payments of punishments on time.

Livingstone \& Lund (1992), Routh \& Burgoyne (1989), Lea, Webley \& Walker (1995) and Schor (1998), claim in their studies that the individuals are affected from psychological factors. By contrast the emerging, behavioural approach to poverty has started to look in-depth at the cognitive, motivational and even sociological limits on action. (Anand \& Lea, 2011). Behavioral economists analyze the results of the psychological factors that influence the human behaviors like attitude, motivation and expectation through the phases of savings, consumption, production and pricing (Can, 2012: 96).

The demand flexibility is really low at closed economy whereas, the demand flexibility is high at open economy. As a consequence, the behavioral choice alternatives of the individuals are getting considerably wider. For instance; the effectiveness of the little price differences on the selection of the brand and the differentiation of consumer choices show that the individual's economic decisions are influenced by the psychological factors (Foxall \& Schrezenmaier, 2003: 676).

As it is seen, the studies conducted in the field of behavioral economics confirm that the individuals are in an irrational manner during the economic decision making procedure. In order to contribute this field, a research on individuals was planned. The factors that affect the psychology of the individual were tried to be determined. 


\section{The Objective and the Methodology of Research}

The studies conducted up to this date defends that the individuals take different economic decisions affecting from different factors psychologically. The objective of this research is to consider the behavioral research of the pharmacists among the drug sector which is one of the product groups of health sector. The influence of the marketing strategies of drug firms on the sales of pharmacies among the drugs which are noticed evidently is researched. Drug firms improve new strategies for increasing the demand. Because it is thought that these strategies are effective on the decision making. Therefore, the question of the research was determined as "Are the pharmacies influenced from the promotional activities of the drug firms while they are selling their products and services?" In this direction, by an empiric study, a relationship between the marketing strategies of the firms and the sales of the products was tried to be established.

Most of the drugs are sold with prescription in all over the world. However, some drugs which do not make serious effects after usage or the drugs used at easily cured illnesses can be sold without prescription. The drugs sold with prescriptions are not included in this research. The purpose of the study is related with the drugs that the consumer demand with his rational choice. Morally, the sales which are not contrary to ethical standards of the profession were studied.

The main population of this research is the pharmacies in İstanbul. The research is restricted by the pharmacies that can be easily reached because of the size of the population. The control groups are the pharmacies in Maltepe, Kartal and Kadıköy which are the provinces of İstanbul. Random sampling was used.

150 pharmacies were interviewed. The recycle of our questionnaire is 100 percent. The restriction of the research is that; the questions were prepared for the drugs used without prescription. The drugs that are used with prescription were not included because of the ethical factors.

The research model is composed of one dependent, three independent variables. These are the introduction of the product, the product amount without invoice and promotional activities. The hypotheses are below:

$\mathrm{H}_{1}$ : The promotional activities of drug firms influence the sales.

$\mathrm{H}_{2}$ : Product sales without invoice influence the sales.

$\mathrm{H}_{3}$ : Advertising and promotion influence the sales.

\subsection{Results}

Since not only the pharmacists but also the personnel employed at the pharmacy answered the questionnaire, the personal information belonging to the pharmacists who answered the questionnaire were not taken into consideration. For the data analysis, the frequencies and percentages were utilized. Chi-square test ${ }^{3}$ was used for the measurement of the decisions related to the relationship between variables. The general reliability of the questions was found as $\alpha=$ 0,502 . The test results are low because of the minority of the number of questions. However, for the research, the number of questions is thought as sufficient.

\footnotetext{
${ }^{3}$ The test is applied when you have two categorical variables from a single population. It is used to determine whether there is a significant association between the two variables.
} 
Öztopcu, A., \& Karaağaoğlu, N. (2016). The influence of promotional activities on the economic decision making. Journal of Human Sciences, 13(3), 4613-4626. doi:10.14687/jhs.v13i3.3947

\subsection{Frequency Tables}

Question 1: Do the information given by the drug firms influence your sales of products?

Table-2: The Efficiency of Being Informed by Drug Firms

\begin{tabular}{lll}
\hline & Number & Percent $\mathbf{( \% )}$ \\
\hline Totally agree & 56 & 37,3 \\
Partially agree & 68 & 45,3 \\
Do not agree & 24 & 16,0 \\
Have no idea & 2 & 1,3 \\
\hline Total & 150 & 100 \\
\hline
\end{tabular}

Figure-1: Bar Figure of the Efficiency of Being Informed by Drug Firms

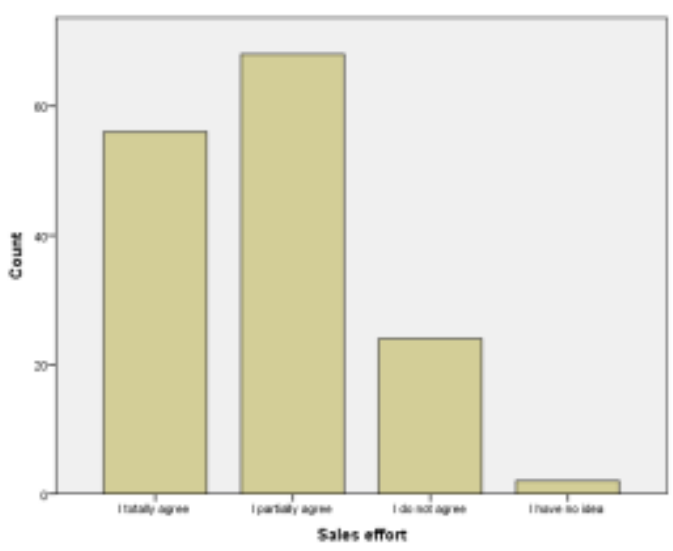

37,3 percent of pharmacies (56 pharmacies) answered as totally agree to the opinion of sales drive are efficient, 45,3 percent ( 68 pharmacies) partially agree, 16 percent ( 24 pharmacies) do not agree, 1,3 percent ( 2 pharmacies) have no idea. 82,6 percent of the pharmacists who answered the questionnaire were understood that they are satisfied with the sales and promotion instruments used by the drug firms.

Question 2: Are the promotion instruments used by drug firms important for you?

Tablo-3: The Efficiency of the Promotion Instruments

\begin{tabular}{lll}
\hline & Number & Percent $\mathbf{( \% )}$ \\
\hline Totally agree & 18 & 12 \\
Partially agree & 68 & 45,3 \\
Do not agree & 59 & 39,3 \\
Have no idea & 5 & 3,3 \\
\hline Total & 150 & 100 \\
\hline
\end{tabular}


Öztopcu, A., \& Karaağaoğlu, N. (2016). The influence of promotional activities on the economic decision making. Journal of Human Sciences, 13(3), 4613-4626. doi:10.14687/jhs.v13i3.3947

Figure-2: Bar Figure of the Efficiency of the Promotion Instruments

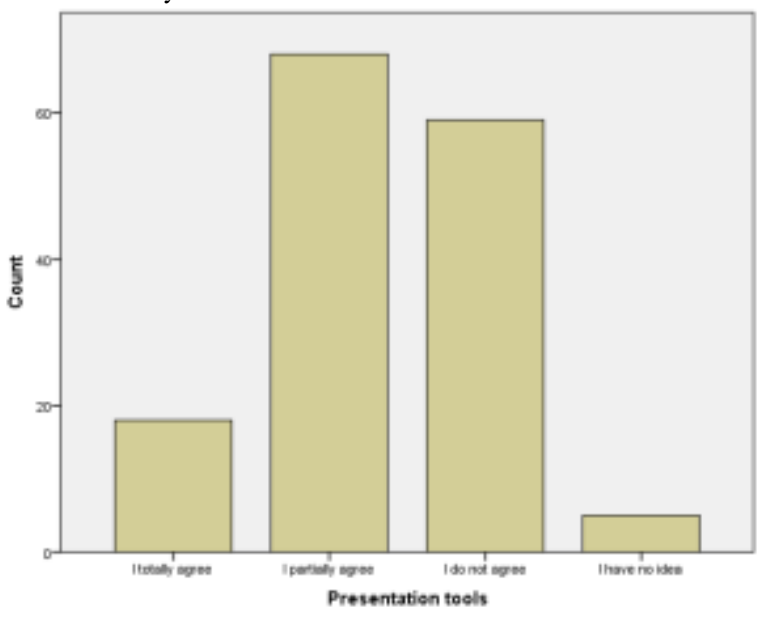

12 percent of pharmacies (18 pharmacies) answered as totally agree to the opinion of promotion instruments of the drug firms are efficient for gaining the consumers, 45,3 percent (68 pharmacies) partially agree, 39,3 percent (59 pharmacies) do not agree, 3,3 percent (5 pharmacies) have no idea. 57,3 percent of the pharmacists are satisfied with the promotion related to drugs. The pharmacists have a negative approach to the efficiency of promotion instruments compared with the satisfaction of general marketing promotions.

Question 3: Does the quantity of commodity without invoice offered by drug firms simplify the sales?

Table-4: Simplification of Buying by the Quantity of Commodity without Invoice

\begin{tabular}{lll}
\hline & Number & Percent $\mathbf{( \% )}$ \\
\hline Totally Agree & 15 & 10 \\
Partially Agree & 58 & 38,7 \\
Do Not Agree & 62 & 41,3 \\
Have No Idea & 15 & 10 \\
\hline Total & 150 & 100 \\
\hline
\end{tabular}

Figure-3: Bar Figure of Simplification of Buying by the Quantity of Commodity without Invoice

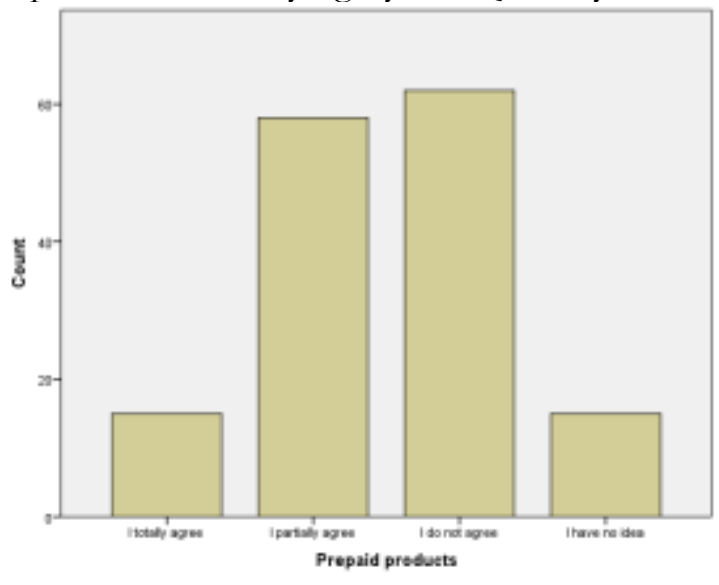


10 percent of pharmacies (15 pharmacies) answered as totally agree to the opinion of the quantity of commodity without invoice given in the promotional campaign is efficient for the sales of the drug, 38,7 percent (58 pharmacies) partially agree, 41,3 percent (62 pharmacies) do not agree, 10 percent (15 pharmacies) have no idea. As in many sectors, about the quantity of commodity without invoice which is not so ethical, 48,7 percent of the pharmacies consider that the drugs given without invoice are effective in the sales and recommendation of that drug, whereas 51,3 percent defends that it does not effect. The point that has to be taken into account is in the case of discount, it can affect the sales of that drug. According to this hypothesis $\mathrm{H}_{2}$ is accepted.

Question 5: Do the opportunities and advantages offered by drug firms simplify the sales?

Table-5: The Efficiency of the Promotion for the Sales

\begin{tabular}{lll}
\hline & Number & Percent $\mathbf{( \% )}$ \\
\hline Totally Agree & 5 & 3,3 \\
Partially Agree & 35 & 23,3 \\
Do not Agree & 69 & 46 \\
Have No Idea & 41 & 27,3 \\
\hline Total & 150 & 100 \\
\hline
\end{tabular}

Figure-4: Bar Figure of the Efficiency of the Promotion for the Sales

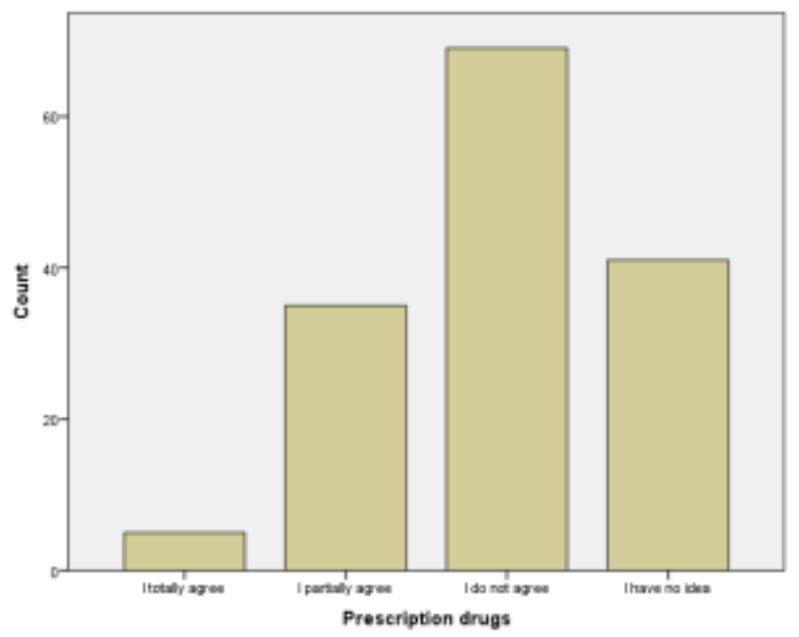

3,3 percent of the pharmacies ( 5 pharmacies) answered the opinion of the promotion conducted by the drug firms for the new drugs which will enter the market is efficient for the customers who buy drugs without prescription, 23,3 percent (35 pharmacies) partially agree, 46 percent ( 69 pharmacies) do not agree, 27,3 percent (41 pharmacies) have no idea. Because of the insufficient knowledge about the new drugs for the market, the promotion conducted by the drug firms are efficient for 26,6 percent of pharmacies, whereas 74,3 percent of them abstain. Therefore, insufficiency of knowledge influences the opinion of the pharmacists for recommendation and sales of the drug without doctor prescription.

As a result of Sample K-S (Kolmogorov-Smirnov) test made for the questionnaire, sig- 2 result is $0,000<0,005$, therefore, it is understood that there is not a normal distribution. For this reason, non-parametric analysis was made. 
Öztopcu, A., \& Karaağaoğlu, N. (2016). The influence of promotional activities on the economic decision making. Journal of Human Sciences, 13(3), 4613-4626. doi:10.14687/jhs.v13i3.3947

\subsection{The Results of $X^{2}$ Test}

The results of the tests for determining statistically whether there is a significant relationship between the four questions $\left(\mathrm{H}_{0}\right.$ : There is no relationship, $\mathrm{H}_{1}$ : There is relationship) at the significance level of $\alpha=0,05$ and various freedom degrees are given below.

It is understood that there is a significant relationship between the questions 1 and 2 as a result of the $\chi^{2}$ test made at 5 percent significance level. In the comparison of chi-square test statistics and chi-square table values, since $X^{2}=26,480,0,002<0,05$, the observed value is higher than the expected value. $H_{0}$ hypothesis was rejected. According to the Question 1; Sales drive conducted by the drug firms are efficient for pharmacists. According the Question 2; the promotion instruments given by the drug firms are efficient for reaching the consumers. In this context, it is seen that the pharmacists have positive approach to first and second questions.

They use the material in his promotional efforts of pharmaceutical companies, there is a significant relationship between the presentation and the adequacy of documentation. The promotional campaigns and tools used affect drug sales. Accordingly, $\mathrm{H}_{1}$ and $\mathrm{H}_{3}$ hypotheses are accepted.

It is understood that there is a significant relationship between the questions 1 and 3 as a result of the $\chi^{2}$ test made at 5 percent significance level. In the comparison of chi-square test statistics and chi-square table values, since $X^{2}=16,309,0,005<0,05$ the observed value is higher than the expected value. $\mathrm{H}_{0}$ hypothesis was rejected. According to the Question 1; Sales drive conducted by the drug firms are efficient for pharmacists, while according to the Question 3, it is seen that the pharmacists have positive approach to efficiency of quantity of commodity given without invoice on the sales of the drug. Accordingly, $\mathrm{H}_{1}$ and $\mathrm{H}_{2}$ hypotheses are accepted.

A significant relationship could not be found between the questions 1 and 4 as a result of the $\chi^{2}$ test made at 0,05 significance level. In the comparison of chi-square test statistics and chi-square table values, since $X^{2}=8,047,0,5>0,05$, the observed value is lower than the expected value. $H_{0}$ hypothesis was not rejected. According to the Question 1; Sales drive conducted by the drug firms are efficient for pharmacists. According to the Question 4, the pharmacists have positive approach for the efficiency of promotion conducted for new products at the sales of drugs without prescription. Therefore, the marketing activities are effective in the sales of the drugs without prescription. $\mathrm{H}_{1}, \mathrm{H}_{2}$ and $\mathrm{H}_{3}$ hypotheses are accepted.

It is understood that there is a significant relationship between the questions 2 and 3 as a result of the $X^{2}$ test made at 0,05 significance level. In the comparison of chi-square test statistics and chisquare table values, since $X^{2}=34,9750,00<0,05$, the observed value is lower than the expected value. $H_{0}$ hypothesis was rejected. According to the Question 2, the promotion materials given by drug firms are efficient for reaching the customers. According to the Question 3, it is seen that the pharmacists have positive approach for the efficiency of the quantity of commodity given without invoice at buying the drugs. In this regard, there is no relationship between the amount invoiced goods and materials used for the sales.

It is understood that there is a significant relationship between the questions 2 and 4 as a result of the $X^{2}$ test made at 0,05 significance level. In the comparison of chi-square test statistics and chisquare table values, since $X^{2}=23,745,0,005<0,05$ the observed value is equal to the expected 
value. $\mathrm{H}_{\mathrm{o}}$ hypothesis was not rejected. According to the Question 2, the promotion materials given by drug firms are efficient for reaching the customers. According to the Question 4, it is seen that the pharmacists have positive approach for the efficiency of the promotion conducted for new products by the drug firms at the sales of the drugs without prescription. Other marketing activities and materials used for drug introductions in this direction there is a significant relationship. Therefore, $\mathrm{H}_{1}$ and $\mathrm{H}_{3}$ hypotheses are accepted.

It is understood that there is a significant relationship between the questions 3 and 4 as a result of the $X^{2}$ test made at 0,005 significance level. In the comparison of chi-square test statistics and chisquare table values, since $X^{2}=17,767,0,003<0,05$ the observed value is higher than the expected value. $H_{0}$ hypothesis was rejected. According to the Question 3; it is seen that the pharmacists have negative approach for the efficiency of the quantity of commodity given without invoice at buying the drugs whereas, according to the Question 4, the pharmacists have positive approach for the efficiency of promotion conducted for new products at the sales of drugs without prescription.

\section{Conclusion}

The traditional economic theory defines the individual as selfish. Behavioral economics starts with the observation of the economic behaviors in a country. Today's economic theories and behavioral economic studies illustrate that the human being act more emotionally and under the influence of other's behaviors and environmental factors. In this context, behavioral economics defends that cooperation of psychology and economy rather than making the synthesis of the disciplines.

In this research, whether the pharmacies are influenced by the marketing activities of the firms or not was tried to be measured. The results indicate that the pharmacists are psychologically affected by the discounts, gifts or other advantages and take economic decisions in this direction. From the healthcare sector view, marketing studies made by the firms affect sector workers. For this reason, pharmacists show irrational behavior. According to classic economics approach, people show rational behavior. However, according to neoclassical economy, people show different behavior uncertainty.

This is interesting, because over the decades, neoclassical thought generally diverged from this possibility of people acting "irrationally." As neoclassical economics evolved, it tended to be characterized by attention to methodological (including mathematical) improvements, but also by an avoidance of appeals to psychology. In general, human behavior was removed as a factor in the economic process, since everyone was assumed to act rationally - there was no room for "irrationality." At this stage, behavior economic researches assert that rational behavior theory is not valid everywhere.

According to the results of the analysis of the data collected in the research, the marketing activities conducted by the drug firms are sufficient for the pharmacies' choice of drugs for their customers. Additionally, the campaigns and the sales drive are effective in the brand choice. Having a positive opinion about the efficiency of the sales drive and material used shows that the promotional activities and the materials used by the drug firms are sufficient and correct. However, there is a negative approach to the opinion of the effectiveness of the quantity of commodity given without invoice on the sales of the drugs. The effect of the firms' politics is quite important on the psychology of the consumer. The most important reason of this case is the presence of the asymmetric knowledge about a special product group like drug. The pharmacists were observed to behave ethically while answering the question. On the other hand, the opposite of this expression was noticed by the informal discussions with the drug firms. 
As a consequence, healthcare payment is very important for economic concepts like GDP, GDP per capita, GINI index and HDI. The marketing campaigns of the firms can be determinative on the healthcare expenses. Whereas the private sector spends great amounts of money and attention on marketing, government and non-for-profits, typically do not. In the healthcare sector, whereas it seems that the primary buyer is the patients, the real determinants are the doctors and the pharmacists. One of the reasons of the pharmacists" choice of " $y$ " brand instead of " $x$ " brand is the marketing activities held by the drug firms. It is regarded that they are partially influenced from these activities and demonstrate an irrational behavior at the choice of the drug for their customers. Accordingly, this research indicates that the individuals can behave irrationally because of the psychological factors. How irrational behaviors are shaped can be determined by neuroeconomics and the experimental studies.

\section{Reference}

Akerlof, G. A., \& Kronton, R. E. (2000). Economics and Identity. The Quartely Journal of Economics, 115(3), 715-753.

Akın, Z. (2013). Davranışsal İktisat-2 (Hangi Ülkelerde Hangi Uygulamalar Var?). drzaferakin.blogspot.com.tr/2013/04/davranssal-iktisat-2-hangi-ulkelerde.btml. Retrieved kasim 2015, from drzaferakin.blogspot.com.tr/2013/04/davranssal-iktisat-2-hangiulkelerde.html

Aksoy, T. \& Şahin, I. (2009). Belirsizlike. Altında Karar Alma: Geleneksel ve Modern Yaklaşımlar. Türkiye Ekonomi Kurumu, Tartışma Metni.

Anand, P., \& Lea, S. (2011). The Psychology and Behavioural Economics of Poverty. Journal of Economic Psychology(32), 284-293.

Ariely, D., Loewenstein, G., \& Prelec, G. (2003). Coherent Artbitrariness: Stable Demand Curves Wihtout Stable Preferences. The Quartely Journal of Economics, 118(1), 73-106.

Azar, H. A. (2012). On the relationship of economic psychology and behavioral economics. journal of economic psychology, 33, 662-664.

Basılgan, M. (2013). İktisat ve Deneysel Yöntem: Deneyler, Tartışmalar ve Gelecek. İ.Ü. Siyasal Bilgiler Fakültesi Dergisi, 48, 61-89.

Binmore, K., \& Shaked, A. (2009). Experimental Economics: Where Next? Journal of Economic Behavior and Organization.

Bolton, G. E., \& Ockenfels, A. (2012). Behavioral Economic Engineering. Journal of Economic Psychology, 33, 665-676.

Büyüköztürk, Ş. (2011). Sosyal Bilimler İ̧in İleri Analiæ̧i El kitabı (22. ed.). Ankara: Pegem Yayınevi.

Camerer, C. F. (1999). Behavioral economics: Reunifying psychology and economics. Proceedings of the National Academy of Sciences of the United States of America, 96(19), 10575-10577.

Camerer, C. F. (2002). Behavioral Economics: Past, Present, Future. Division of Humanities and Social Sciences, 228-277.

Camerer, C. F., Loewenstein, G., \& Prelec, D. (2005). Neuroeconomics: How Neuroscience Can Inform Economics. Journal of Economic Literature, 43, 9-64.

Can, Y. (2012). İktisatta Psikolojik İnsan Faktörü. Davramıssal İktisat. Hukuk ve İktisat Araștrmalar Dergisi, 4(2), 91-98.

Colander, D. (2004). The Art of Teaching Economics. International Review of Economics Education, 3(1), 63-76.

Çalık, G., \& Düzü, Ü. (2009). İktisat ve Psikoloji. Akademik Bakış. Uluslararası Hakemli Sosyal Bilimler e-Dergisi.(18). 
Öztopcu, A., \& Karaağaoğlu, N. (2016). The influence of promotional activities on the economic decision making. Journal of Human Sciences, 13(3), 4613-4626. doi:10.14687/jhs.v13i3.3947

DíCLemente, D. F., \& Hantula, D. A. (2003). Applied Behavioral Economics and Consumer Choice. Journal of Economic Psychology, 24, 589-602.

Eren, E. (2009). Yeni İktisatta" Ortak Noktalar. İktisatta Yeni Yaklassımlar Callşstay.

Etzioni, A. (2010). Behavioral economics: A methodological note. Journal of Economic Psychology, 31, 51-54.

Foxall, G. R., \& Schrezenmaier, T. C. (2003). The Behavioral Economics of Consumer Brand Choice: Establishing a Methodology. Journal of Economic Psychology, 24, 675-695.

Frank, R. H. (2006). Microeconomics and Behavior. New York, America: McGraw-Hill Irwin.

Glimcher, P. W., Camerer, C. F., Fehr, E., \& Poldrack, R. A. (2009). Introduction: A Brief History of Neuroeconomics. Neuroeconomics: Decision Making and the Brain. USA.

Gorvett, R. (2012). Behavioral Economics and Its Implications for Enterprise Risk Management. Call Paper for the 2012 ERM Symposium.

Green, D. M. \& Swets, J. A. (1966). Signal Detection Theory and Psychophysics. New YorkWiley.

Harford, T. (2008). The Logic of Life. Newyork: Random House. ISBN: 978-1-58836-682-5

Kahneman, D., \& Smith, V. (2002). Kahneman, D. \& Smith, V. (2002). Foundations of Behavioral and Experimental Economics. Advanced information on The Prize in Economic Sciences, 1-25.

Kahneman, D., \& Tversky, A. (1979). Prospect theory: An analysis of decisions under risk. Econometrica, 47(2), 313-327.

List, J. A. (2011). Why Economists Should Conduct Field Experiments and 14 Tips for Pulling One Off. Journal of Economic Perspectives, 25(3), 3-16.

Mill, J. S. (1967). Essays on Economics and Society , . In J. M. Robson (Ed.). Toronto and London, England and USA: University of Toronto Press .

Nakano, T. (2007). Alfred Marshall's economic nationalism. Nations and Nationalism, 13(1), 57-76.

Rubin, E. L. (2005). Rational Choice and Rat Choice: Some Thoughts on the Relationship Among Rationality, Markets, and Human Beings. Chrcago-Kent Law Review(89), 1091-1127.

Samson, A. (2014). The Behavioral Economics Guide 2014. Retrieved from www.behavioraleconomics.com

Samuelson, P. A., \& Nordhaus, W. D. (1985). Economics (12th ed.). New York: McGraw-Hill.

Schneider, S. (2010). Homo Economicus- or More Like Homer Simpson? . Deutch Bank Research.

Simon, H. A. (1955). A Behavioral Model of Rational Choice., 69(1), 99-118. The Quartely Journal of Economics, 69(1), 99-118.

Şeniğne, B. (2011). Rasyonalite Kavramına Deneysel ve Davranıssal İktisat Bağlamında Yeni Bir Bakış Açısı: "Nöroiktisat". Yayımlanmamış Doktora Tezi, Marmara Üniversitesi, Sosyal Bilimler Enstitüsü.

Thaler, R. H., \& Mullainathan, S. (2000). Behavioral Economics. MIT Dept. of Economics Working Paper, 00(27).

Tversky, A. \& Kahneman, D. (1986). Rational Choice and the Framing of Decisions. The Journal of Business, 59(4), 251-278.

Von Neumann, J., \& Morgenstern, O. (1953). Theory of Games and Economic Behavior. Princeton: NJ. Princeton University Press.

Yalçın, Y. (2012). Davranışsal İktisat Yaklaşımıyla Rekabetçi Piyasa Analizi. Rekabet Kurumu Yayinlar, (298). 